\title{
NEW ELECTRON BEAM EQUIPMENT AND TECHNOLOGIES FOR PRODUCING OF ADVANCED MATERIALS USING VACUUM MELTING AND EVAPORATION METHODS DEVELOPED AT SPE «ELTEKHMASH»
}

\author{
N.I. GRECHANYUK, P.P. KUCHERENKO, A.G. MELNIK, I.N. GRECHANYUK, \\ Yu.A. SMASHNYUK and V.G. GRECHANYUK \\ SPE «Eltekhmash» \\ 25 Vatutin Str., 21011, Vinitsa, Ukraine. E-mail: vin25ebt@ukr.net
}

\begin{abstract}
The paper presents the designs of laboratory and production electron beam equipment, developed at SPE «Eltekhmash». Recent achievements of the Company in the following fields are briefly considered: development of industrial technologies for producing heat-resistant alloys and items from them for coating deposition by electron beam and ion-plasma methods; powders for plasma deposition of coatings, and special titanium alloys for medicinal purposes. 11 Ref., 6 Tables, 10 Figures.
\end{abstract}

Keywords : electron beam melting, evaporation of metals and alloys, electron beam equipment for melting and evaporation, alloys and powders for gas turbine construction and medicine

At present it is difficult to visualize development of many industrial sectors without application of modern electron beam technologies. Electron beam equipment and technologies are the object of numerous multidisciplinary research and development. Scientists from US, Germany, France, Great Britain, Japan and Ukraine made significant contribution into its progress.

Work [1] presents the results of development of electron beam equipment and technologies for producing materials and coatings, performed at scientific-production enterprise «Eltekhmash» (Ukraine) in the period from 2005 to 2015.

This review is devoted to analysis of the results of development of new generation of electron beam equipment and technologies in this company over the last 10 years. The company is intensively developing several directions of electron beam technology, including:

- development of laboratory and industrial equipment for melting metals and alloys, deposition of protective coatings, producing composite materials condensed from the vapour phase;

- producing high-purity $\mathrm{Ni}-\mathrm{W}$ alloys, used as seeds in growing single-crystal blades;

- production of special titanium alloys for biomedical purposes;

- master alloy production;

- production of quality ingots from scrap of high-temperature alloys JS26-VI and JS32;
- manufacturing tubular billets-cathodes from $\mathrm{Ni}$ $\mathrm{Cr}-\mathrm{Al}-\mathrm{Y}, \mathrm{Ni}-\mathrm{Co}-\mathrm{Cr}-\mathrm{Al}-\mathrm{Y}$ heat-resistant alloys for ion-plasma coating deposition;

- producing special metal powders for plasma deposition of coatings;

- production of electric contacts;

- deposition of protective coatings on gas turbine blades.

Development of versatile laboratory and pilot-production electron beam equipment with different functional capabilities, which are currently realized in specialized units, allows saving time and funds for development of new technological processes. L-2 unit belongs to this type of equipment. Figure 1 gives the general view of the unit.

Specification of EB unit L-2

Dimensions of evaporated billets (ingots), mm: diameter . . . . . . . . . . . . . . . . 70 length . . . . . . . . . . . . . . not more than 400 Dimensions of billets melted from upper mechanism, mm: diameter ...................... 80 length . . . . . . . . . . . . . not more than 390

Dimensions of condensation surfaces, mm, not more than:

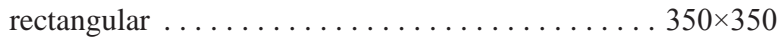
round $\ldots \ldots \ldots \ldots \ldots \ldots \ldots \ldots \ldots \ldots \ldots \ldots \ldots \ldots \ldots \ldots \ldots$ cylindrical:

diameter ......................... 200

length ................... 350

Distance from evaporation surface to condensation

surface, $\mathrm{mm}$. . . . . . . . . . . . . . . 200-325

Number of crucibles, pcs . . . . . . . . . . . . . 3

Speed of evaporated ingot displacement, $\mathrm{mm} / \mathrm{min} \ldots$. . . 1-350 


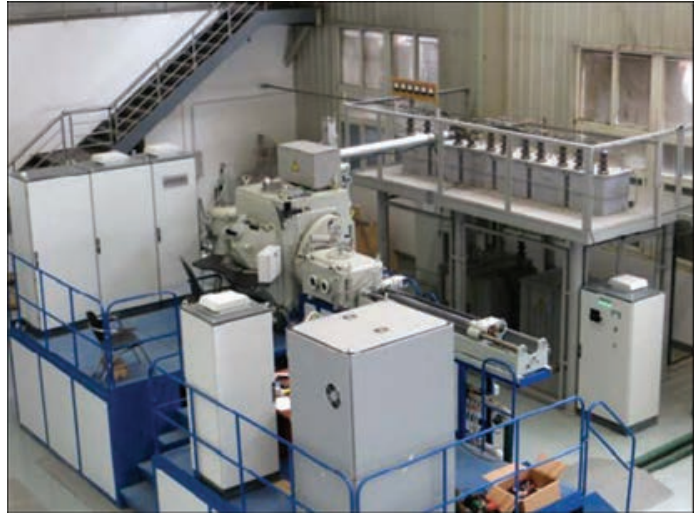

Figure 1. Appearance of EB unit L-2

Speed of displacement of billets melted from

the top, $\mathrm{mm} / \min \ldots \ldots \ldots \ldots \ldots \ldots \ldots \ldots \ldots$. $5-350$

Speed of item rotation on horizontal shaft, rpm . . . . . . . 3-25

Speed of item rotation on vertical shaft, rpm . . . . . . . 5-70

Number and power $(\mathrm{kW})$ of electron beam guns

(thermal cathode guns with strip cathode):

for material evaporation from the crucibles . . . . . . . 3×60

for heating from above . . . . . . . . . . . . . . . . . 2×60

for heating from below $\ldots \ldots \ldots \ldots \ldots \ldots \ldots 1 \times 60$

Consumed power, $\mathrm{kW}$, not more than:

high-voltage power source . . . . . . . . . . . . . . . . 250

power source of ion cleaning device ........... 30

Rated accelerating voltage, $\mathrm{kV} \ldots \ldots \ldots \ldots \ldots \ldots \ldots 20$

Working vacuum in the chambers, $\mathrm{Pa}(\mathrm{mm} \mathrm{Hg}) \ldots 6 \cdot 10^{-3}-1 \cdot 10^{-2}$

.......................... $\left(5 \cdot 10^{-3}-1 \cdot 10^{-4}\right)$

Overall dimensions of the unit, mm, not more than:

length . . . . . . . . . . . . . . . . . . . . . 4300

width ............................ 6200

height . . . . . . . . . . . . . . . . . . . . . 3300

Unit weight, $t \ldots \ldots \ldots \ldots \ldots \ldots \ldots \ldots \ldots \ldots \ldots \ldots$

The unit allows realization of four types of different technological processes.

The first of them is coating deposition on various items, in particular turbine blades (Figure 2). Three independent copper water-cooled crucibles of $70 \mathrm{~mm}$ diameter allow, simultaneously or independently, performing evaporation of three different materials by a set program, and forming heat-resistant, metal, ceramic or metal-ceramic, single-layer and multilayer graded coatings. Modern requirements to vacuum hy-

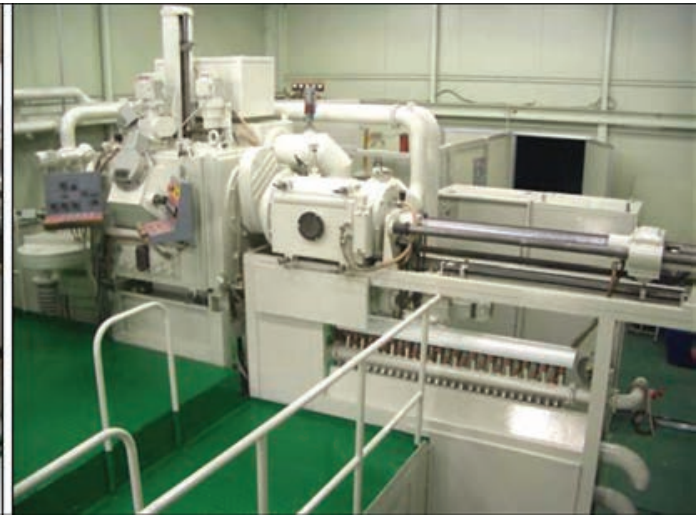

giene at coating deposition are satisfied due to design features of the unit (two-chamber variant). Loading and unloading of initial (uncoated) and coated blades (items) are performed in reloading chamber without breaking the vacuum in the main working chamber, where the actual technological process of deposition is conducted.

Second technological task solved in this unit is producing condensed from the vapour phase composite materials of dispersion-strengthened, microlaminate or microporous type. At evaporation from three independent crucibles the vapour flow is deposited on a stationary or rotating substrate from steel of St.3 grade of $500 \mathrm{~mm}$ diameter and up to $20 \mathrm{~mm}$ thickness (Figure 3). For easy separation of condensed material from the substrate a thin separating layer is applied on the deposition surface. Composite sheet blanks of $500 \mathrm{~mm}$ diameter and 0.1 to $7 \mathrm{~mm}$ thickness are produced.

A new technological direction of L-2 unit application is producing dispersed metal, ceramic and composite powders (Figure 4). A feature of producing powders is vapour flow condensation on a rotating substrate cooled to room temperature. An enamel coating is first applied onto the substrate surface. The above technique practically eliminates interaction of the deposited material with the substrate. The loose residue is scraped off the substrate surface and is fed
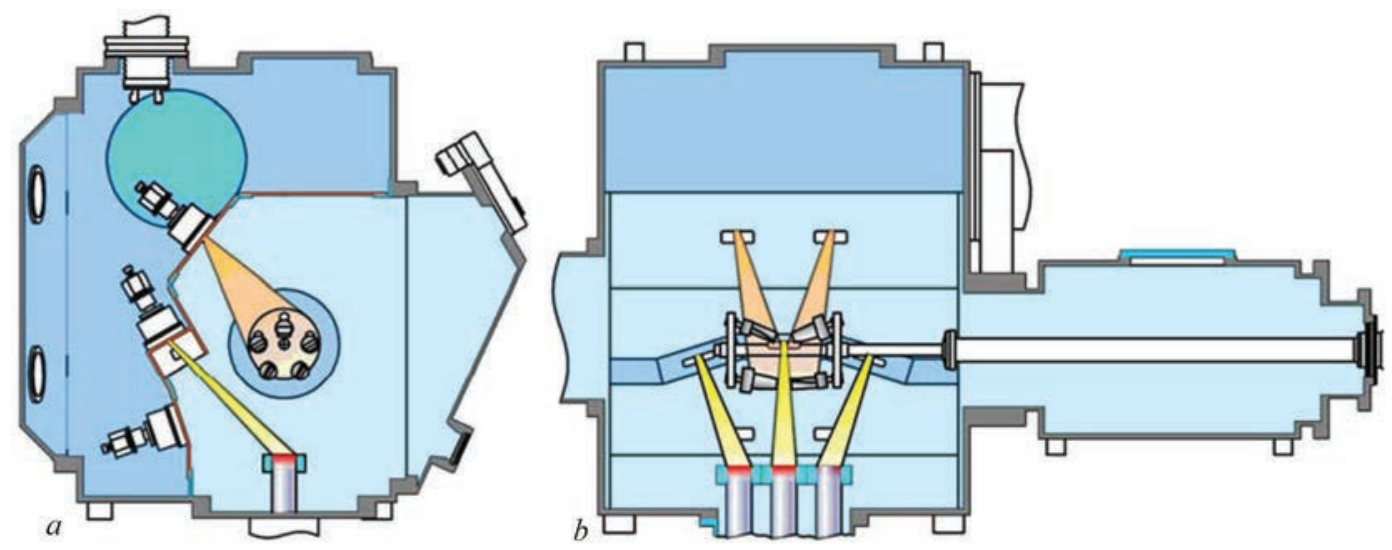

Figure 2. Schematic of coating deposition on gas turbine blades: $a-$ side view; $b-$ front view 


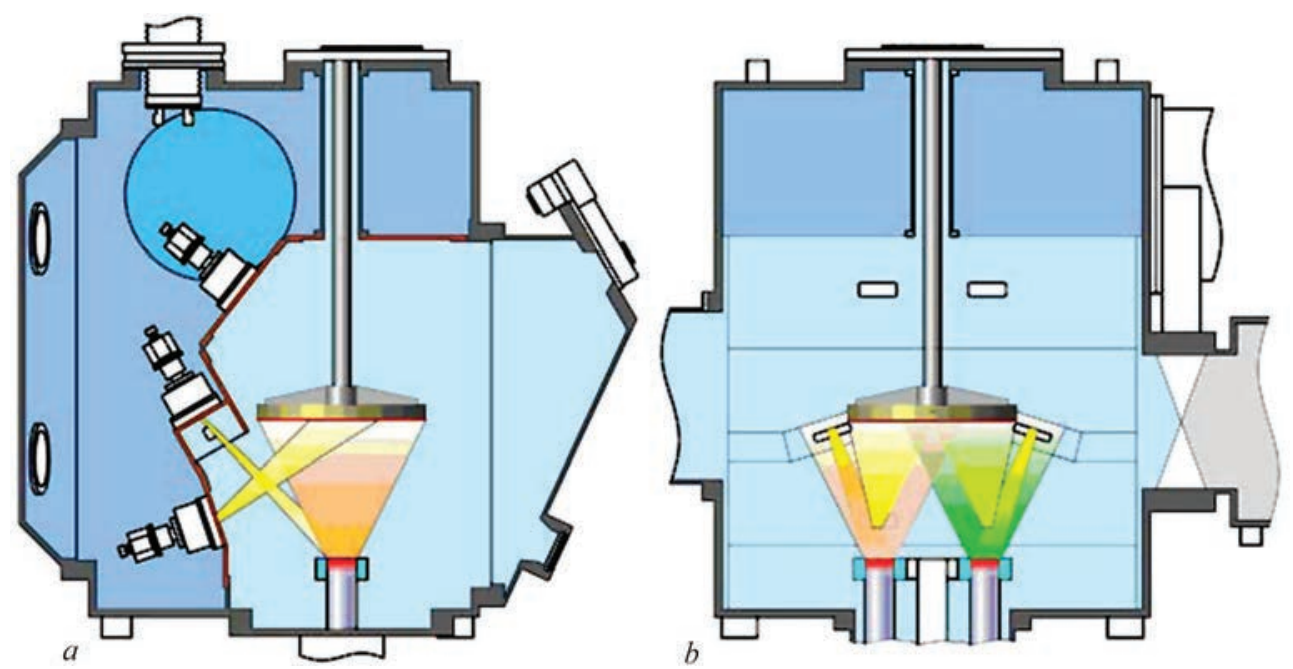

Figure 3. Schematic of producing composite materials condensed from the vapour phase: $a$ — top view; $b$ - front view
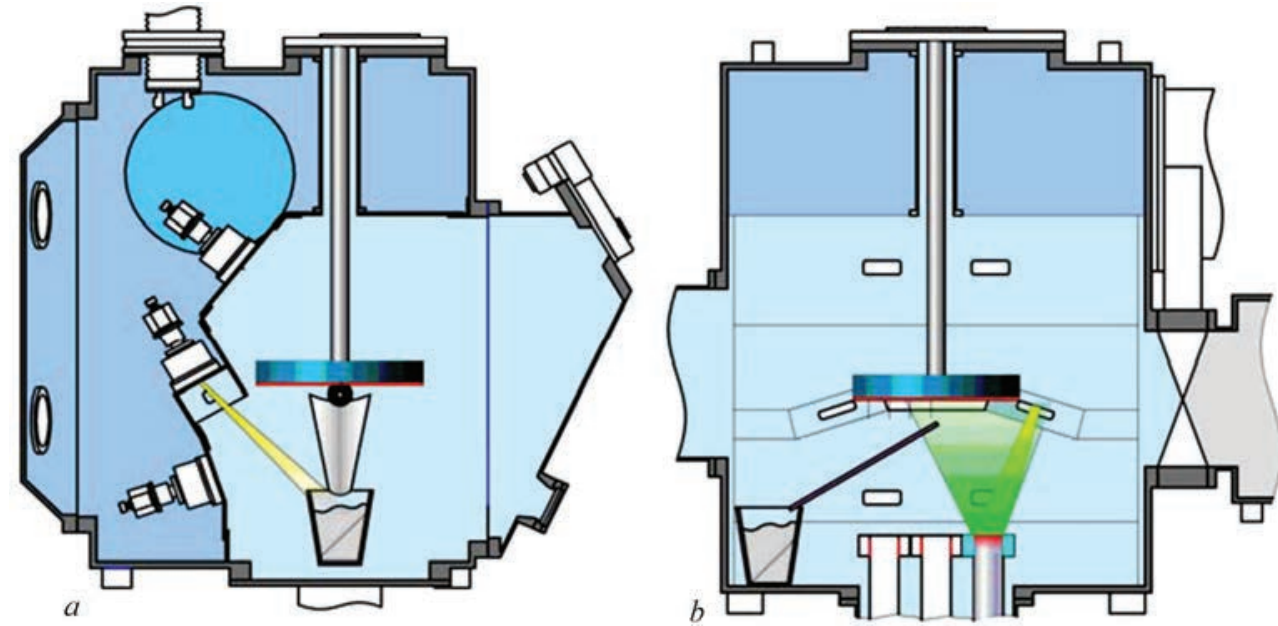

Figure 4. Schematic of producing powders from the vapour phase: $a$ - side view; $b$ - front view

into powder collection tank through vibrating feeder. Produced powders are of a round shape, their diameter varying from 0.4 to $5 \mu \mathrm{m}$.

The fourth technological process which is realized in the unit is producing ingots of pure metals and alloys (Figure 5).

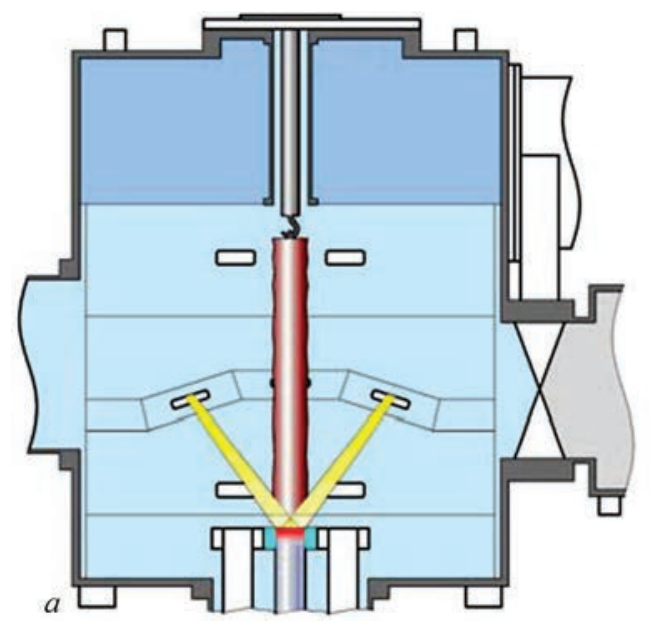

Variant given in Figure 5, $a$ is used mainly to produce ingots of refractory metals and alloys. Here, the consumed (remelted) billet is suspended from the upper rotation mechanism. A certain speed of billet rotation is set and the first electron beam gun is used to perform melting of its end face. Liquid metal pen-

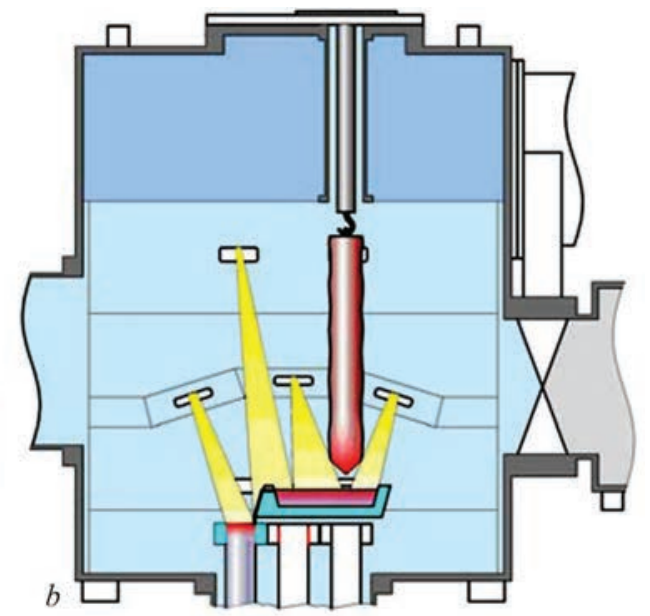

Figure 5. Process chart of producing ingots (alloys) in L-2 unit: $a$ - remelting directly into the mould; $b$ - remelting through intermediate crucible into the mould 
etrates directly into the copper water-cooled crucible, where the electron beam of the second gun forms the ingot. Melting through the intermediate crucible is the most extensively applied (Figure 5, b). Such technological process provides maximum refining of remelted material from interstitial impurities and nonmetallic impurities.

At present special attention is given to development of specialized electron beam equipment for deposition of thermal barrier coatings (TBC) on blades. Leading world manufacturers include ALD Vacuum Technologies, Von Ardenne, Pratt and Whitney, and PWI.

SPE «Eltekhmash» developed new generation production electron beam unit L-8 for deposition of TBC on turbine blades [2]. Unit appearance is shown in Figure 6. Schematic of technological process of coating deposition in the unit working chamber is given in Figure 7.

\section{Specification of EB unit L-8}

Dimensions of cylindrical cassette with parts, $\mathrm{mm}$, not more than: diameter . . . . . . . . . . . . . . . . . . . 250 length ........................... 500

Speed of item rotation on horizontal shaft, rpm $\ldots \ldots . \quad 0.5-50$

Number of evaporators, pcs . . . . . . . . . . . . . 4

Crucible inner diameter, $\mathrm{mm} \ldots \ldots \ldots \ldots \ldots \ldots \ldots$

Length of evaporated ingots, $\mathrm{mm}$. . . . . . . . not more than 500

Ingot feed rate, $\mathrm{mm} / \mathrm{min} \ldots \ldots \ldots \ldots \ldots \ldots . .6 .5-350$

Distance from upper edge to cassette rotation axis

or condensation plane, mm . . . . . . . . . . . . . . . . . . . . . 350

Number and nominal power $(\mathrm{kW})$ of electron beam guns:

for material evaporation from crucibles ........ $4 \times 100$

for item heating ...................... . 2×60

Type of electron beam guns - axial guns with cold cathode

(based on high-voltage glowing discharge)

Consumed power, $\mathrm{kW}$, not more than:

high-voltage power sources . . . . . . . . . . . . . . . . 520

auxiliary equipment $\ldots \ldots \ldots \ldots \ldots \ldots \ldots \ldots$

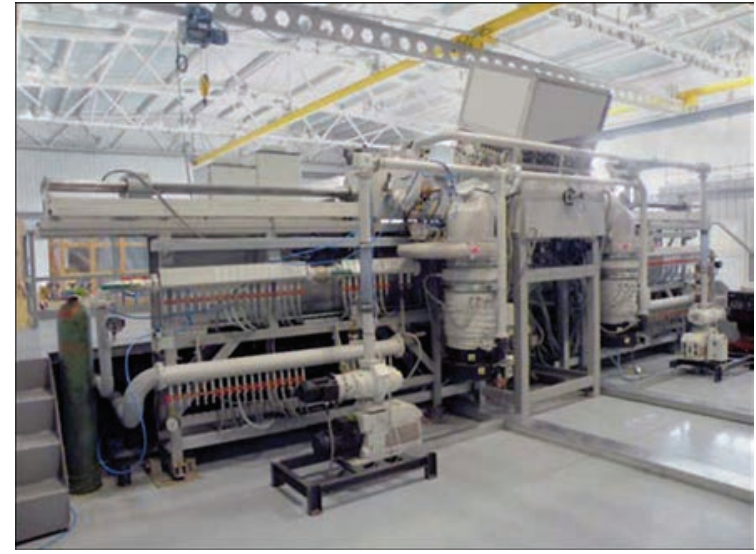

Figure 6. Appearance of EB unit L-8

Rated accelerating voltage, $\mathrm{kV} \ldots \ldots \ldots \ldots \ldots \ldots \ldots$

Working vacuum in the chambers, $\mathrm{Pa}(\mathrm{mm} \mathrm{Hg})$ :

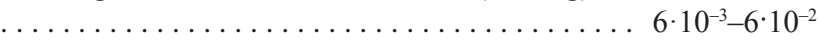

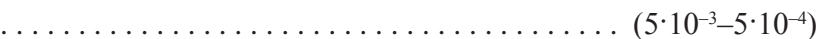

Unit overall dimensions, mm, not more than:

length . . . . . . . . . . . . . . . . . . . . . . . 10500

width ............................. 9500

height . . . . . . . . . . . . . . . . . . . . . . . 4300

Weight of the unit (with power source), $t$. . n not more than 25

A feature of L-8 unit is application of gas-discharge guns with up to $1000 \mathrm{~h}$ operating life and deposition of all types and structures of protective coatings: metal, ceramic, composite, single-layer, multilayer, graded, etc. TBC of complex composition and structure on turbine blades can be formed in one process cycle.

Two reloading (lock) chambers of the unit accommodate devices, providing ion cleaning of blades before coating deposition, blade preheating, and formation of barrier microlayers on the boundaries: blade - inner heat-resistant layer; inner heat-resistant layer - outer ceramic layer for slowing down the diffusion processes on interfaces.
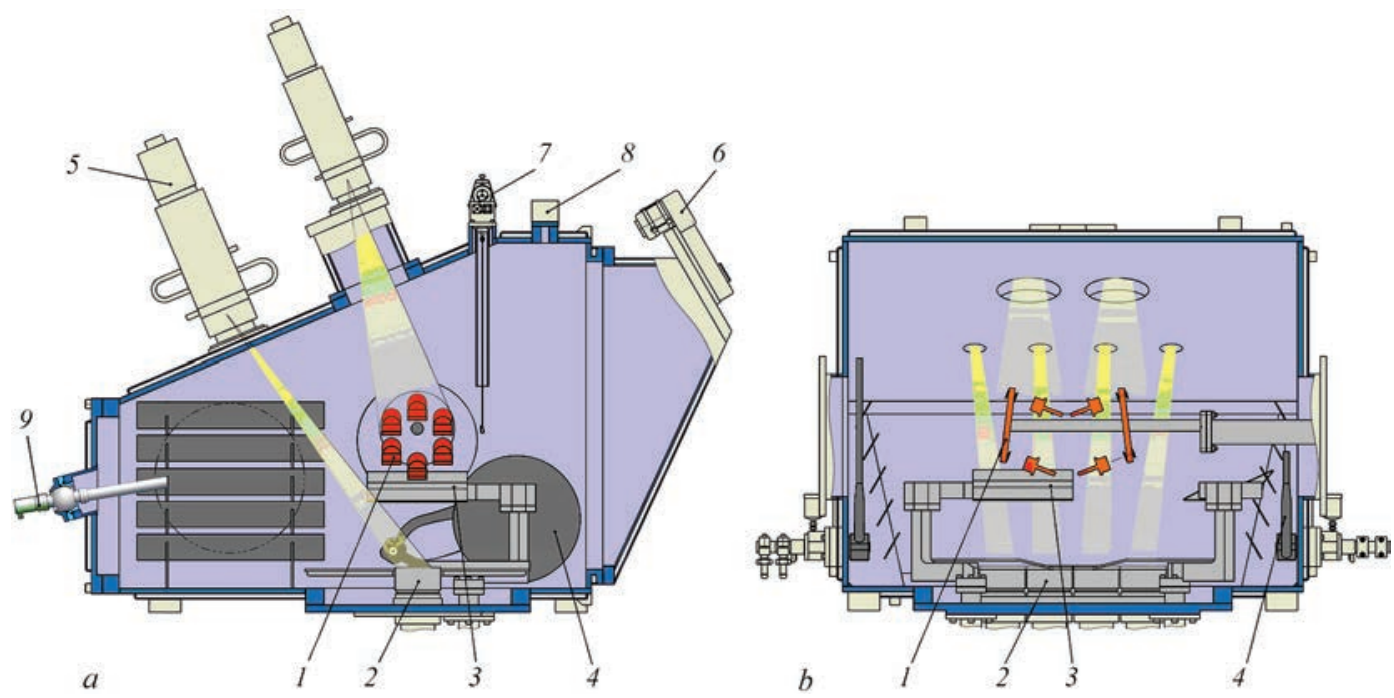

Figure 7. Schematic of technological process of coating deposition in unit working chamber: $a$ - cross-sectional view; $b$ - longitudinal view; 1 - cassette with blades; 2 - crucibles; 3 - evaporator gate valves; 4 - lock gates valves; 5 - electron beam gun; 6 - viewing system; 7 - load cell; 8 - process gas leak valve; 9 - ball lead-in for pyrometer mounting 


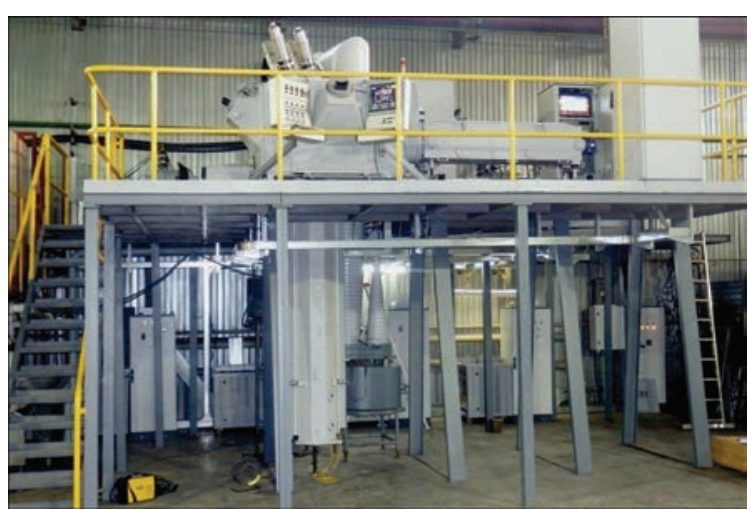

Figure 8. Appearance of EB unit L-4

Sensor for controlling deposited coating thickness is mounted on working chamber upper wall, and ball lead-in with sighting tube and viewing window for contactless measurement of item temperature, using high-technology infrared pyrometer and special software, are mounted on working chamber rear wall.

The unit also supports the possibility of partial ionization of technological gas and metal vapour by applying negative bias to the item (up to $2 \mathrm{kV}$ ). Ionization promotes improvement of coating quality and their adhesion to the item being protected.

Advantages of electron beam remelting, compared to other methods (vacuum-arc and vacuum-induction) are the highest quality of material refining under vacuum, as well as high degree of production purity. Possibility of controlling the process allows reproducing the parameters to ensure the required alloy composition.

SPE «Eltekhmash» developed and put into commercial operation production electron beam unit L-4 for refining and melting of metals and alloys with application of cold-cathode (gas discharge) guns as the heat source [3]. General view of the unit is shown in Figure 8 . Schematic of process chamber, in which

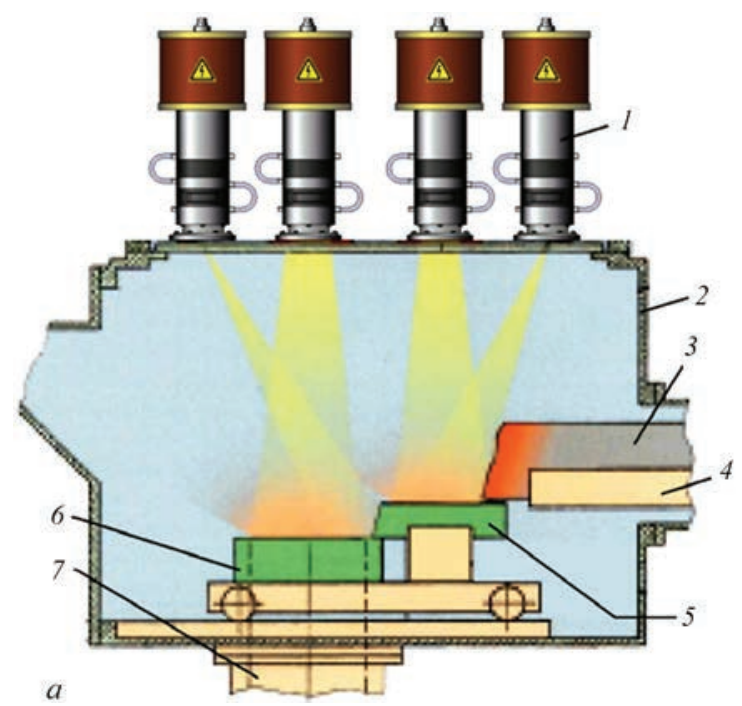

meting and refining of metals and alloys are performed, is given in Figure 9.

\section{Specification of EB unit L-4}

Maximum size of remelted billet, mm . . . . . . . 200×200 $\times 150$ Maximum size of melted ingot, mm.......... Ø300×1900 Maximum size of melted slab, mm ......... 200×300×1900 Diameters of moulds in the unit set, mm . . . . . Ø70, 100, 130 Overall dimensions, $\mathrm{mm}$............... 200 200300

Dimensions of metal liquid pool surface in intermediate crucible, mm . . . . . . . . . . . . . . . . . . . 300 $\times 300$ Number and maximum power $(\mathrm{kW})$ of electron

heaters .......................... $4 \times 100$ Maximum gun current, A . . . . . . . . . . . . 3.3

Rated accelerating voltage, $\mathrm{kV} \ldots \ldots \ldots \ldots \ldots \ldots$

Consumed power, $\mathrm{kW}$, not more than:

electron beam gun power sources. . . . . . . . . . 400

auxiliary equipment $\ldots \ldots \ldots \ldots \ldots \ldots \ldots \ldots \ldots$

Vacuum in working chamber, $\mathrm{Pa}(\mathrm{mm} \mathrm{Hg}) \ldots 1.3 \cdot 10^{-2}-1.3 \cdot 10^{-1}$

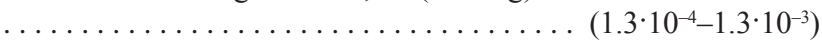

Cooling water pressure, $\mathrm{Pa}\left(\mathrm{kg} / \mathrm{cm}^{2}\right) \ldots \ldots \ldots 3 \cdot 10^{5}-4 \cdot 10^{5}(3-4)$

Unit overall dimensions, mm:

length . . . . . . . . . . . . . . . . . . 7000

width ............................6600 6000

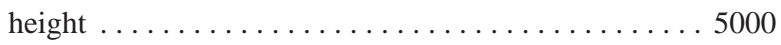

Equipment allows producing high-quality ingots and slabs of the required chemical composition from such traditional metals as iron, nickel, cobalt, copper, highly-reactive refractory metals as titanium, niobium, zirconium, tungsten, hafnium, high-temperature and heat-resistant alloys, $\mathrm{Ti}_{3} \mathrm{Al}, \mathrm{TiAl}, \mathrm{Ni}_{3} \mathrm{Al}, \mathrm{NiAl}$ and other intermetallics.

Producing ingots and tubular billets from $\mathrm{Me}-$ $\mathrm{Cr}-\mathrm{Al}-\mathrm{Y}$ alloys for electron beam and ion-plasma coating deposition. The Company has mastered commercial production of a range of ingots for electron beam coating deposition, in accordance with TU U 27.4-20113410.002-2001 (version 3) [4]. Ingot composition is given in Table 1.

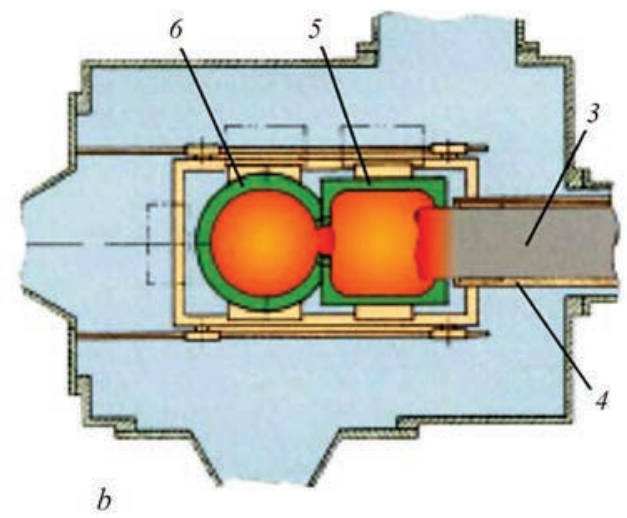

Figure 9. L-4 unit process chamber: $a$ - front view; $b$ - top view; 1 - electron bean gun; 2 - working chamber; 3 - remelted material; 4 - pullout tray; 5 - intermediate crucible; 6 - mould; 7 - ingot drawing mechanism 
More than $10 \mathrm{t}$ of ingots of different chemical composition have been manufactured. At present M3P-6 ingots are supplied to Company «Zorya-Mashproekt» (Nikolaev), as well as to People's Republic of China.

Commercial production of tubular billets-cathodes from M3P-1 alloy for ion-plasma deposition of high-temperature coatings in MAP-1, MAP-2, MAP3 units was started. Cathode appearance is shown in Figure 10.

Electron beam technology of tubular billet casting allows an essential improvement of cathode quality and, eventually, of the quality of coatings deposited from them, as well as refusing to purchase them from RF.

Production of quality ingots for casting blades from high-temperature alloy wastes. Wastes of high-temperature alloys in casting production are technologically unavoidable remains of the initial alloy, not included into quality ingot weight. The importance of the problem of refining high-temperature alloy wastes consists in that a considerable quantity of wastes, caused by casting rejects, mould defects, presence of crop, etc., accumulate at GTE manufacturing enterprises in the process of producing blades from initial materials. High cost of primary high-temperature alloys led to appearance of a tendency of application of casting

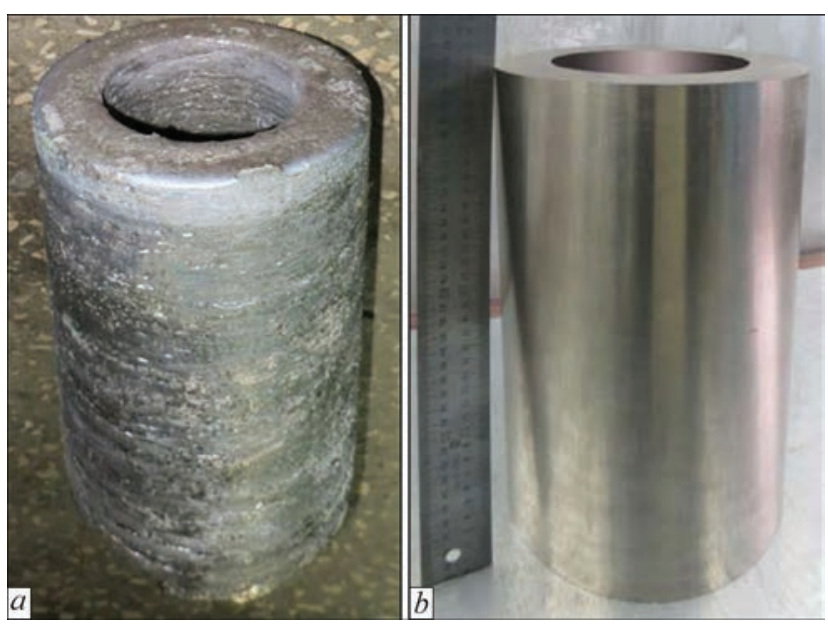

Figure 10. Appearance of tubular cathodes for ion-plasma coating deposition: $a$ - in initial state; $b$ - after machining

production wastes in blending melts for blade casting that allows lowering product cost [5].

«Eltekhmash» developed an original commercial electron beam technology of processing high-temperature alloy JS26-VI. Results of chemical analysis of produced ingots after machining, $95-97 \mathrm{~mm}$ in diameter and of 300-320 mm length, is given in Table 2.

Data given in the Table confirm the complete correspondence of ingot composition to requirements of TU-92-177-91. Electron beam remelting (EBR) leads

Table 1. Composition of ingots for electron beam coating deposition

\begin{tabular}{|c|c|c|c|c|c|c|c|c|c|c|c|}
\hline \multirow{2}{*}{ Designation } & \multicolumn{5}{|c|}{ Elements, wt.\% } & \multicolumn{6}{|c|}{ Impurities, wt.\%, up to } \\
\hline & Co & $\mathrm{Ni}$ & $\mathrm{Cr}$ & $\mathrm{Al}$ & $\mathrm{Y}$ & $\mathrm{Hf}$ & $\mathrm{Zr}$ & $\mathrm{Si}$ & $\mathrm{Fe}$ & $\mathrm{Cu}$ & $\mathrm{C}$ \\
\hline M3P-1 & Base & $0-2$ & $20-24$ & $10-13$ & $0.4-1$ & 0.2 & 0.4 & 0.5 & 0.3 & 0.06 & 0.06 \\
\hline M3P-2 & Same & $8-12$ & $18-24$ & $10-13$ & $0.4-1$ & 0.2 & 0.4 & 0.5 & 0.3 & 0.06 & 0.06 \\
\hline M3P-3 & $»$ & $0-2$ & $21-25$ & $10-13$ & $0.4-1$ & 0.2 & 0.4 & 0.5 & 0.3 & 0.06 & 0.06 \\
\hline M3P-4 & $»$ & $8-12$ & $18-24$ & $10-13$ & $0.4-1$ & 0.2 & 0.4 & 0.5 & 0.3 & 0.06 & 0.06 \\
\hline M3P-5 & $18-22$ & Base & $18-24$ & $10-13$ & $0.4-1$ & 0.2 & 0.4 & 0.5 & 0.3 & 0.06 & 0.06 \\
\hline M3P-6 & - & Same & $18-24$ & $10-13$ & $0.4-1$ & 0.2 & 0.4 & 0.5 & 0.3 & 0.06 & 0.06 \\
\hline M3P-7 & - & $"$ & $18-24$ & $10-13$ & $0.4-1$ & 0.2 & 0.4 & 0.5 & 0.3 & 0.06 & 0.06 \\
\hline M3P-8 & $8-10$ & $"$ & $18-24$ & $10-13$ & $0.4-1$ & 0.2 & 0.4 & 0.5 & 0.3 & 0.06 & 0.06 \\
\hline M3P-9 & - & - & $18-24$ & $10-13$ & $0.4-1$ & 0.2 & 0.4 & 0.5 & Base & 0.06 & 0.06 \\
\hline
\end{tabular}

Table 2. Composition of billet-casting of $97 \mathrm{~mm}$ diameter produced from recycled alloy JS26-VI by EBR

\begin{tabular}{|c|c|c|c|c|c|c|c|c|c|c|}
\hline \multirow{2}{*}{ Sampling location } & \multicolumn{10}{|c|}{ Element content, wt.\% } \\
\hline & C & $\mathrm{Cr}$ & Co & $\mathrm{W}$ & $\mathrm{Al}$ & $\mathrm{Ti}$ & Mo & $\mathrm{Fe}$ & $\mathrm{Nb}$ & V \\
\hline Top & 0.137 & 4.70 & 8.96 & 11.50 & 6.10 & 1.02 & 1 & 0.06 & 1.43 & 0.90 \\
\hline Middle & 0.129 & 4.94 & 9.03 & 11.53 & 5.74 & 0.90 & 1 & 0.06 & 1.64 & 0.91 \\
\hline Bottom & 0.132 & 4.94 & 9.03 & 11.53 & 5.74 & 0.90 & 1 & 0.06 & 1.64 & 0.91 \\
\hline TU 1-92-177-91 & $0.12-0.17$ & $4.3-5.3$ & $8.7-9.3$ & $11.2-12.0$ & $5.6-6.1$ & $0.8-1.2$ & $0.8-1.2$ & $\leq 0.5$ & $1.4-1.8$ & $0.8-0.2$ \\
\hline
\end{tabular}

Table 2 (cont.)

\begin{tabular}{|c|c|c|c|c|c|c|c|}
\hline \multirow{2}{*}{$\begin{array}{c}\text { Sampling } \\
\text { location }\end{array}$} & \multicolumn{7}{|c|}{ Element content, wt.\% } \\
\cline { 2 - 8 } & $\mathrm{Ni}$ & $\mathrm{Si}$ & $\mathrm{Mn}$ & $\mathrm{S}$ & $\mathrm{P}$ & $\mathrm{O}_{2}$ & $\mathrm{~N}_{2}$ \\
\hline Top & Base & $<0.2$ & $<0.3$ & 0.003 & 0.003 & 0.00068 & 0.00109 \\
\hline Middle & Base & $<0.2$ & $<0.4$ & 0.003 & 0.003 & 0.00070 & 0.00106 \\
\hline Bottom & Base & $<0.2$ & $<0.3$ & 0.003 & 0.003 & 0.00074 & 0.00105 \\
\hline TU 1-92-177-91 & Base & $\leq 0.2$ & $\leq 0.3$ & $\leq 0.005$ & $\leq 0.010$ & $\leq 0.002$ & $\leq 0.002$ \\
\hline
\end{tabular}


Table 3. Chemical composition of titanium alloys of $\mathrm{Ti}-\mathrm{Nb}-\mathrm{Zr}-$ Si system

\begin{tabular}{|c|c|c|c|}
\hline $\begin{array}{c}\text { Alloy } \\
\text { number }\end{array}$ & $\mathrm{Nb}$ & $\mathrm{Si}$ & $\mathrm{Zr}$ \\
\hline 1 & $11-13$ & $0.9-1.1$ & $1.9-2.2$ \\
\hline 2 & $11-13$ & $0.9-1.1$ & $3.9-4.2$ \\
\hline 3 & $11-13$ & $0.9-1.1$ & $5.9-6.2$ \\
\hline 4 & $11-13$ & $0.9-1.1$ & $9.9-10.2$ \\
\hline 5 & $11-13$ & $0.9-1.1$ & $14.8-15.2$ \\
\hline 6 & $18-20$ & $0.9-1.1$ & $1.9-2.2$ \\
\hline 7 & $18-20$ & $0.9-1.1$ & $3.9-4.2$ \\
\hline 8 & $18-20$ & $0.9-1.1$ & $5.9-6.2$ \\
\hline 9 & $18-20$ & $0.9-1.1$ & $9.9-10.2$ \\
\hline 10 & $18-20$ & $0.9-1.1$ & $14.8-15.2$ \\
\hline
\end{tabular}

to essential reduction of the content of such impurities as sulphur, phosphorus, oxygen and nitrogen. As to their quality, the ingots after EBR exceed the initial material (billets of Ø80) produced by OJSC $« \mathrm{CM}$ Kompaniya» (Stupino, RF) in vacuum furnace by equiaxed crystallization.

Ingots of JS26-VI alloy after EBR, produced from recyclable wastes, have passed the full testing cycle at Company «Motor-Sich» (Zaporozhie) and are now used as initial materials in casting gas turbine blades. First batch of ingots of JS-32 alloy in the quantity of $300 \mathrm{~kg}$ was also produced by EBR of the respective wastes.
Master alloy production. Commercial production of $\mathrm{Ni}-\mathrm{Y}$ master alloys is performed in keeping with TU 48-0531-464-93. Experimental batches of master alloys Al-Mo, Al-Ni, Al-Zr are produced.

Titanium alloy production. Experimental batches of $\mathrm{Ti}-\mathrm{Nb}-\mathrm{Zr}-\mathrm{Si}$ system alloys are produced for Ukrainian and US users. Alloy composition is given in Table 3.

As is seen from the Table, titanium-based alloys are produced in a quite narrow range of alloying component concentrations. Here, repeatability in the melts reaches $95-98 \%$. Ti-Nb-Zr-Si system alloys are designed for medical purposes.

Production of metal powders of $\mathrm{Co}-\mathrm{Cr}-\mathrm{Al}-\mathrm{Y}-$ Si system for plasma deposition of coatings. Production of powders of $\mathrm{Co}-\mathrm{Cr}-\mathrm{Al}-\mathrm{Y}-\mathrm{Si}$ system for plasma deposition of coatings has been mastered recently $[4,6,7]$. Tables 4 and 5 give chemical composition of ingots and powders made from them.

Ingots for powder manufacture were produced by EBR of pure initial components. Powders of 40$100 \mu \mathrm{m}$ fractions are made by the method of chemical fragmentation of respective ingots. Production batches of powders of $\mathrm{Co}-\mathrm{Cr}-\mathrm{Al}-\mathrm{Y}$ system are supplied to Company «Zorya-Mashproekt» and PRC.

Table 4. Chemical composition of alloys for Co-based powder manufacturing

\begin{tabular}{|c|c|c|c|c|c|c|c|c|c|c|}
\hline \multirow{2}{*}{ Designation } & \multicolumn{4}{|c|}{ Elements, wt.\% } & \multicolumn{5}{c|}{ Impurities, wt.\%, up to } \\
\cline { 2 - 11 } & $\mathrm{Ni}$ & $\mathrm{Cr}$ & $\mathrm{Al}$ & $\mathrm{Y}$ & $\mathrm{Si}$ & $\mathrm{Hf}$ & $\mathrm{Zr}$ & $\mathrm{Fe}$ & $\mathrm{Cu}$ & $\mathrm{C}$ \\
\hline M3P-10 & $0-2$ & $26-0$ & $6-9$ & $0.8-1.2$ & $1.5-4.0$ & 0.2 & 0.4 & 0.3 & 0.06 & 0.06 \\
\hline M3P-11 & $0-2$ & $20-25$ & $10-13$ & $0.4-0.1$ & $1.5-4.0$ & 0.2 & 0.4 & 0.3 & 0.06 & 0.06 \\
\hline
\end{tabular}

Table 5. Chemical composition of Co-based powders for plasma deposition of coatings

\begin{tabular}{|l|c|c|c|c|c|c|c|c|c|c|}
\hline \multirow{2}{*}{ Designation } & \multicolumn{9}{|c|}{ Elements, wt.\% } & \multicolumn{4}{c|}{ Impurities, wt.\%, up to } \\
\cline { 2 - 11 } & $\mathrm{Ni}$ & $\mathrm{Cr}$ & $\mathrm{Al}$ & $\mathrm{Y}$ & $\mathrm{Si}$ & $\mathrm{Hf}$ & $\mathrm{Zr}$ & $\mathrm{Fe}$ & $\mathrm{Cu}$ & $\mathrm{C}$ \\
\hline M3P-10 & $0-2$ & $26-30$ & $6-9$ & $0.8-1.2$ & $1.5-4.0$ & 0.2 & 0.4 & 0.6 & 0.06 & 0.1 \\
\hline M3P-11 & $0-2$ & $20-25$ & $10-13$ & $0.4-0.1$ & $1.5-4.0$ & 0.2 & 0.4 & 0.6 & 0.06 & 0.1 \\
\hline
\end{tabular}

Table 6. Electron beam equipment supplied by Company «Eltekhmash» in 2005-2014

\begin{tabular}{|l|l|c|c|}
\hline \multicolumn{1}{|c|}{ Description } & \multicolumn{1}{|c|}{ Purpose } & Year & Customer \\
\hline Electron beam unit L-1 & Deposition of protective coatings from vapour phase in vacuum & 2005 & Ukraine \\
\hline Electron beam unit L-4 & Refining and remelting of metals and alloys in vacuum & 2006 & Armenia \\
\hline $\begin{array}{l}2 \text { power units with HVGD-based guns of } 220 \mathrm{~kW} \\
\text { each }\end{array}$ & $\begin{array}{l}\text { Commercial production of «solar silicon» from metallurgical } \\
\text { silicon }\end{array}$ & 2007 & Japan \\
\hline $\begin{array}{l}\text { Power unit with HVGD-based guns of 30 kW } \\
\text { power }\end{array}$ & Coating deposition & 2008 & Taiwan \\
\hline $\begin{array}{l}\text { 2 power units with HVGD-based guns of 30 } \\
\text { and } 100 \mathrm{~kW} \text { power }\end{array}$ & Upgrading of units for refining metallurgical silicon & 2008 & Russia \\
\hline $\begin{array}{l}\text { Power unit with HVGD-based gun of 100 kW } \\
\text { power }\end{array}$ & Upgrading of unit for refining and remelting of noble metals & 2010 & Russia \\
\hline $\begin{array}{l}\text { Electron beam unit L-2 } \\
\text { Electron beam unit L-8 }\end{array}$ & $\begin{array}{l}\text { Deposition of protective coatings from the vapour phase in } \\
\text { vacuum }\end{array}$ & $\begin{array}{c}2012 \\
2013\end{array}$ & $\begin{array}{c}\text { Ukraine } \\
\text { China }\end{array}$ \\
\hline
\end{tabular}


Production of electric contracts. The most recent achievements in the field of manufacture of materials for electric contacts and products from them are given in [8-10].

Commercial production of new materials for electric contacts $\mathrm{Cu}(0.05-0.1)(\mathrm{ZrY})-\mathrm{W}$ and $\mathrm{Cu}-(0.05-$ $0.1(\mathrm{ZrY})-\mathrm{Cr}$ has been mastered.

More than 15 composite materials have been produced, from which more than 1.6 mln pieces of electric contacts and electrodes for various national economy applications have been manufactured.

Coating deposition on gas turbine blades. Company «Eltekhmash» realized a closed cycle of coating deposition on turbine blades, including melting of all types of $\mathrm{Ni}$ and Co-based ingots [4], manufacture of $\mathrm{ZrO}_{2}-\mathrm{Y}_{2} \mathrm{O}_{3}$ ceramic ingots [11], and deposition of TBC from the above initial materials of customized design and chemical composition in user equipment $[1,4]$.

Manufacture of industrial electron beam equipment. Table 6 gives the data on enterprise supplies of laboratory and production electron beam equipment for material melting and evaporation in 2005-2014.

Enterprise supplies both individual components of equipment, and laboratory and production electron beam units with complete set of components for realization of technological processes of melting metals and alloys, protective coating deposition, and producing composite materials from the vapour phase.
1. Grechanyuk, N.I., Kucherenko, P.P., Grechanyuk, I.N. (2007) New electron beam equipment and technologies of producing advanced materials and coatings. The Paton Welding J., 5, 25-29.

2. Grechanyuk, N.I., Kucherenko, P.P., Melnik, A.G. et al. (2014) Industrial electron beam installation L-8 for deposition of heat protective coatings on turbine blades. Ibid., 10, 45-50.

3. Grechanyuk, N.I., Kucherenko, P.P., Melnik, A.G. et al. (2016) Industrial electron beam installation L-4 for vacuum remelting and refining of metals and alloys. Poroshk. Metallurgiya, 7/8, 140-149.

4. TU 27.4-201134.10.002-2001: Materials in ingots and powders for protective coatings. Modification No. 3 to KTU. Version 3 of 03.09.2015.

5. (2007) Electron beam melting in foundry. Ed. by S.V. Ladokhin. Kiev: Stal.

6. Grechanyuk, N.I., Gogaev, K.A., Zatovsky, V.G. (2012) Peculiarities of producing powder alloy $\mathrm{Co}-\mathrm{Cr}-\mathrm{Al}-\mathrm{Y}-\mathrm{Si}$. Poroshk. Metallurgiya, 11/12, 18-25.

7. Gogaev, K.O., Grechanyuk, M.I., Grybkov, V.K. et al. Method for producing of complex-alloyed powders on cobalt base. Pat. 99557 Ukraine. Publ. 27.08.2012.

8. Grechanyuk, N.I., Grechanyuk, V.G., Khomenko, E.V. et al. (2016) Modern composite materials for switching and welding equipment. Inf. 2. Application of high-rate vacuum evaporation methods for manufacturing electric contacts and electrodes. The Paton Welding J., 2, 34-39.

9. Grechanyuk, M.I., Grechanyuk, V.G., Bukhanovsky, V.V. et al. Composite material for electric contacts and method of its manufacturing. Pat. 104673 Ukraine. Publ. 25.02.2014.

10. Grechanyuk, M.I., Grechanyuk, I.M., Grechanyuk, V.G. et al. Composite material for electric contacts and method of its manufacturing. Pat. 86434 Ukraine. Publ. 27.04.2009.

11. TU.U-13.2-201134.10-004-2003: Ceramic materials for thermal protection coatings. 